\title{
Can Overuse of Kambô Cause Psychosis?
}

\author{
Renitha Roy ${ }^{1}$, Aparna Baranwal ${ }^{2}$, Eduardo D. Espiridion ${ }^{3}$ \\ 1. Frederick Memorial Hospital, West Virginia School of Osteopathic Medicine, Lewisburg, USA 2. Medical Student, \\ West Virginia School of Osteopathic Medicine, Lewisburg, USA 3. Psychiatry, Frederick Memorial Hospital, Frederick, \\ USA
}

Corresponding author: Eduardo D. Espiridion, edjen19meg@gmail.com

\begin{abstract}
Kambô is an emerging ritual, which involves the application of the toxin produced by Phyllomedusa bicolor to a freshly burnt area to heal chronic diseases of the mind and body. Due to the widespread use of kambô, more cases of symptomatic health conditions are being discovered. In this case study, we report a patient
\end{abstract} with psychosis potentially due to the kambô ritual.

Categories: Psychiatry, Public Health

Keywords: phyllomedusa bicolor, kambô, toxin-induced psychosis, giant leaf frog toxin, shaman ritual, neurochemical effects of toxin

\section{Introduction}

Kambô is an emerging ritual, which involves the application of a toxin produced by a giant leaf frog, Phyllomedusa bicolor, to a freshly burnt skin area. This is being used to heal the chronic diseases of the mind and body. Due to the widespread use of kambô, more cases of symptomatic health conditions are being observed. In this case report, we report a patient who presented with new-onset psychotic symptoms, potentially due to the kambô ritual.

\section{Case Presentation}

The patient is a 33-year-old Caucasian female, who was brought to the local emergency room by the police. The police were repeatedly called by the patient about rapes and shootings in her community. On the day she was brought to the hospital, the patient called the police under a fake name and complained that her husband was raping another individual. She was making nonsensical comments, including being ritualistically haunted by her father and sister. The patient was found to be unmarried and lived alone but was adamant about being married to a celebrity. She had no significant psychiatric history prior to this incident. After acknowledging that she was a certified shaman and practices healing through the utilization of the kambô ritual, she claimed that she uses the kambô toxin to alleviate her chronic pain. Her frequency of performing the ritual changed from once per month to up to nine times per month. She presented with characteristics of paranoia, anxiety, bizarre delusions, labile mood, and panic attacks. On physical examination, scars were noted on the patient's legs from the burns and administration of the toxin. She

Received 05/17/2018

Review began 05/25/2018 Review ended 06/01/2018 Published 06/09/2018

\section{() Copyright 2018}

Roy et al. This is an open access article distributed under the terms of the Creative Commons Attribution License CC-BY 3.0., which permits unrestricted use, distribution, and reproduction in any medium, provided the original author and source are credited. subsequently had an unremarkable extensive medical workup. As part of her treatment plan, the patient was started on risperidone and she gradually improved after nine days in the hospital psychiatry unit.

\section{Discussion}

Phyllomedusa bicolor is a giant leaf frog that secretes toxins that potentially contain peptides, such as phyllokinin, phyllocaerulein, phyllomedusin, sauvagine, deltorphins, dermorphins, and adrenoregulin.

This particular venom is used in a ritual of applying the toxins to a freshly inflicted burn on the body. The rituals are meant to purify the human body. However, there have been case reports of toxic hepatitis, syndrome of inappropriate antidiuretic hormone secretion (SIADH), and even death [1-3]. The toxin is found to have rapid effects of tachycardia, vomiting, and incontinence, which have led to euphoria and sedation [4].

Many components of the toxin have been discovered to have neurochemical effects. Deltorphin is a full selective agonist for the delta opioid receptors in the central nervous system. It has shown an analgesic effect in mice through the morphine (mu) and ketocyclazocine (kappa) opioid receptors [5]. Moreover, dermorphin has been shown to have a high potency and selectivity to the mu opioid receptors but has weak anti-nociceptive properties [6]. Another constituent, sauvagine, is associated with behavioral effects in mice. Sauvagine has effects on the adrenal cortex and corticotrophin-releasing factor (CRF). Data has shown that patients with post-traumatic stress disorder (PTSD) with secondary psychosis had increased levels of CRF, but in the control group with PTSD and no psychosis, CRF levels were within normal limits [7-8]. The patient had multiple doses of the kambô toxin leading to her hospital admission, which potentially had increased her CRF and may have caused her psychotic symptoms. With the various neuropeptides in the kambô toxin, which have known and unknown effects and interactions, any combinations of these 


\section{Conclusions}

This is a patient who presented with significant disorganized behaviors and eccentric delusions without any known psychiatric issues. The only significant information pertaining to her was an increased use of the kambô toxin and her symptoms responded to antipsychotics. Based on the various components of the toxin, there can be a correlation between her psychosis and the overuse of kambô. Even with a recent increase in reported health impacts, there is still uncertainty on the complex toxic effects of the kambô toxin. Since these rituals have been increasing worldwide, such clinical presentations may increase as well.

\section{Additional Information}

\section{Disclosures}

Human subjects: Consent was obtained by all participants in this study. Conflicts of interest: In compliance with the ICMJE uniform disclosure form, all authors declare the following: Payment/services info: All authors have declared that no financial support was received from any organization for the submitted work. Financial relationships: All authors have declared that they have no financial relationships at present or within the previous three years with any organizations that might have an interest in the submitted work. Other relationships: All authors have declared that there are no other relationships or activities that could appear to have influenced the submitted work.

\section{References}

1. Aquila I, Gratteri S, Sacco MA, et al.: The biological effects of kambô: is there a relationship between its administration and sudden death?. J Forensic Sci. 2017, 63:965-68. 10.1111/1556-4029.13641

2. Pogorzelska J, Łapiński TW: Toxic hepatitis caused by the excretions of the Phyllomedusa bicolor frog - a case report. Clin Exp Hepatol. 2017, 3:33-34. 10.5114/ceh.2017.65228

3. Leban V, Kozelj G, Brvar M: The syndrome of inappropriate antidiuretic hormone secretion after giant leaf frog (Phyllomedusa Bicolor) venom exposure. Toxicon. 2016, 120:107-109. 10.1016/j.toxicon.2016.07.007

4. Daly JW, Caceres J, Moni RW, et al.: Frog secretions and hunting magic in the upper Amazon: identification of a peptide that interacts with an adenosine receptor. Proc Natl Acad Sci U S A. 1992, 89:10960-63. 10.1073/pnas.89.22.10960

5. Pescatore R, Marrone GF, Sedberry S, et al: Synthesis and pharmacology of halogenated ס-opioid-selective [d-Ala(2)]deltorphin II peptide analogues. ACS Chem Neurosci. 2015, 6:905-10. 10.1021/acschemneuro.5b00060

6. Bird MF, Cerlesi MC, Brown M, et al.: Characterisation of the novel mixed Mu-NOP peptide ligand dermorphin-N/OFQ (DeNo). PLoS ONE. 2016, 11:e0156897. 2016

7. Risbrough VB, Stein MB: Role of corticotropin releasing factor in anxiety disorders: a translational research perspective. Horm Behav. 2006, 50:550-61. 10.1016/j.yhbeh.2006.06.019

8. Sautter FJ, Bissette G, Wiley J, et al.: Corticotropin-releasing factor in posttraumatic stress disorder (PTSD) with secondary psychotic symptoms, nonpsychotic PTSD, and healthy control subjects. Biol Psychiatry. 2003, 54:1382-88. 10.1016/S0006-3223(03)00571-7 